UDC: 631.356 .023

\title{
STUDY OF THE PROCESS OF PREPARING FEEDING MIXTURES USING THE COMPOSITE MIXER
}

\author{
M. I. Chernovol, M. O. Sviren, R. V. Kisiliov \\ Central Ukrainian National Technical University \\ 8, pr. Universytetsky, Kropyvnytsky, Ukraine, 25030 \\ e-mail:rektor@kntu.kr.ua,kaf_sgm_kntu@ukr.net,ruslan_vik@ukr.net
}

Received on November 27, 2017

\begin{abstract}
Aim. Enhancing the quality and improving the technological process of mixing feeds using the new construction of the mixer and substantiating its rational parameters. Methods. Mathematical modeling theories, fundamentals of using machinery in animal breeding. Results. The estimated model of the functioning of a constructive-technological scheme of a composite mixer and the mathematical model of the dynamic interaction of mixer paddles and the solid mass of feeds were elaborated. It was established that the technological efficiency of preparing the homogeneous mixture depends on physical and mechanic properties of its components, the impact and interaction between the form and geometric parameters of the attacking surface of the paddles, the slope angle, the setting increment and working modes of the mixer. Conclusions. The results of the studies confirm the possibility of enhancing the efficiency of the technology of preparing completely balanced feeding mixtures for cattle via the intensification of the mixing process using the construction of the composite belt-paddle mixer, the elaboration of theoretical fundamentals of the interaction of feed components with the working bodies and substantiating their main constructive and technological parameters.
\end{abstract}

Keywords: feed mixer, feeds, animal breeding, paddle mixer, zootechnic requirements.

DOI: 10.15407 /agrisp5.01.017

\section{INTRODUCTION}

Enhancing the efficiency of animal breeding as an industry depends considerably on the quality of preparing mixtures, as their share takes $30-60 \%$ of expenses in the structure of production costs [1-3]. Progressive technologies, providing for complete implementation of genetic potential of animals, have not been widely applied in Ukraine due to the absence of required technical provisions.

Current constructions of feed mixers for cattle do not meet all the zootechnic requirements to the preparation of multi-component balanced complete feeding mixtures because they are characterized by high energy losses as well as specific consumption of materials. Therefore, the studies, aimed at elaborating the working bodies for feed mixers which will ensure the creation of highly efficient feeding foundation with low expenses of energy and materials, are of economic value [4-6].

(C) M. I. CHERNOVOL, M. O. SVIREN, R. V. KISILIOV, 2018
The aim of the studies is enhancing the quality and improving the technological process of mixing feeds using the new construction of the mixer and substantiating its rational parameters.

\section{MATERIALS AND METHODS}

The methods of mathematical modeling theories and fundamentals of machinery use in feeds mixing were applied in theoretical studies.

\section{RESULTS AND DISCUSSION}

The estimated model of the functioning of a constructive-technological scheme of a composite mixer and the mathematical model of the dynamic interaction of mixer paddles and the solid mass of feeds were elaborated. It was established that the technological efficiency of preparing the homogeneous mixture depends on physical and mechanic properties of its components, the impact and interaction between the form and geometric parameters of the attacking surface of the paddles, the slope angle, the setting increment and working modes of the mixer [7-9]. 


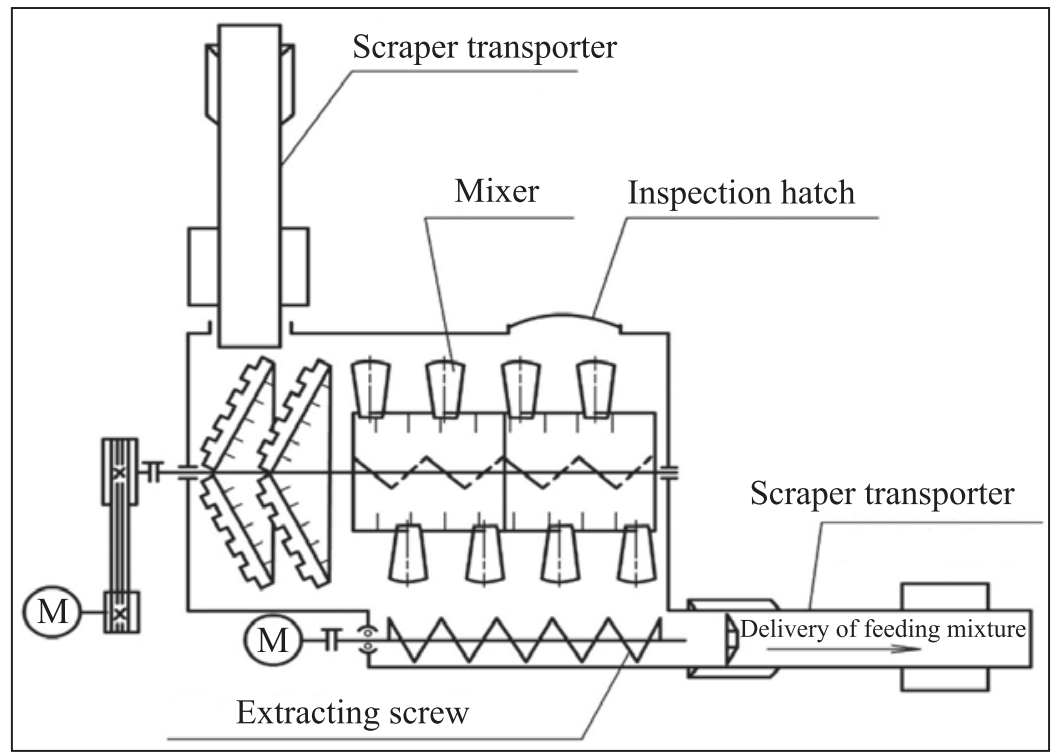

Fig. 1. The technological scheme of a line-paddle mixer of feeds

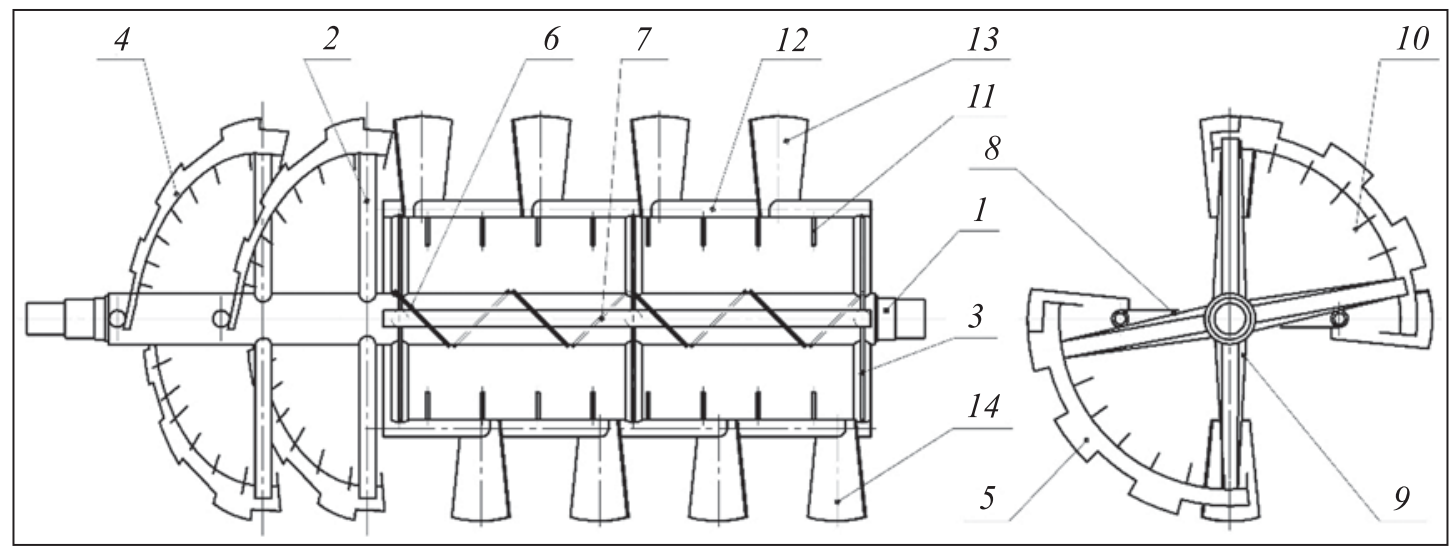

Fig. 2. The technological scheme of an improved composite mixer: 1 - shaft; 2 - frame of a helical mixer; 3 -junction plate of a paddle mixer; 4,5-helical line; 6, 7-left paddle; 8 - frame of a paddle mixer; 9 - junction plate of a helical mixer; 10 , 11 - radial fingers; 12 - horizontal pipe; 13,14 - right paddle

An improved mixer with a combined scheme of the flow of raw materials using multi-section helical, line and flat paddles is suggested for elimination of current drawbacks of traditional mixers (Fig. 1).

To expand the mass, to intensify the process and to enhance the dynamics of mixing the components in the microvolumes, the helical and flat paddles were additionally equipped with radial paddles.

The process of mixing feeds using the improved mixer is done as follows. The corresponding doses of the components of the feeding mixture are loaded in layers into the tank using the composite transporter with gradual leveling of the raw material using the long line helical paddles with fingers and then are supplied into the multi-section mixer with flat paddles (Fig. 2). The paddles of the upper range with the right slope angle separate the mixture portion along the width of the paddle and transport it in radial, circular, and axial directions towards the right end of the mixer, and the second range, with the left slope angle - towards the left end of the mixer, creating a large microvolume mass of the mixture with the discrete content of the shares of the mixture components along with the radial fingers. Here the shares of each mixture component enter the area of interaction of complicated movements, crossings, and collisions, and are periodically transported from one flow to the other which ensures the intense mass exchange and accelerates the process of feed mixing.

The translocation of a feed mixture along the surface of paddles with different slope angle in the zone 


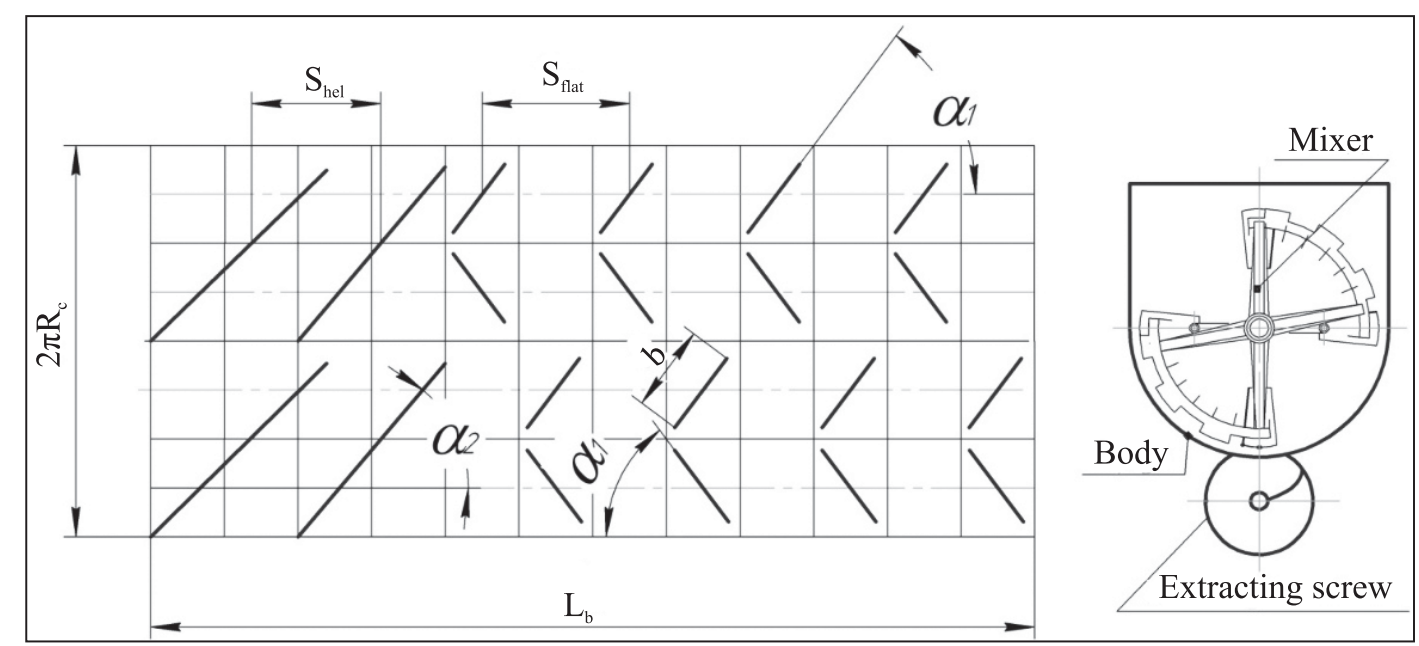

Fig. 3. The scheme of location of helical and flat paddles with a different direction of their slope angle to the axis which are placed along the periphery

of inertial (free) motion is made in the mode of increased dynamics of the process and the increased number of collisions and crossings in the radial and axial directions which is determined by the form and sizes of the attaching paddle, their setting increment, the slope angle and kinematic modes of the work of paddles (Fig. 3).

The determination of kinematics of the motion of a mixture share was conducted with the consideration of the friction forces and the slope angle for paddles [1012]. In case of friction, depending on the slope angle of the paddle towards the shaft axis a the translocation of the material point of the mixture component in the axial direction will occur while the paddle moves by the value of (Fig. 4):

$$
h_{0}=S \cdot \frac{\cos \alpha \cos (\alpha+\varphi)}{\cos \varphi},
$$

lags behind in the axial direction by the value of:

$$
Z_{0}=S \cdot \frac{\sin \alpha \sin (\alpha+\varphi)}{\cos \varphi},
$$

lags behind in the circular direction:

$$
\lambda=S \cdot \frac{\cos \alpha \cdot \sin (\alpha+\varphi)}{\cos \varphi},
$$

where $\alpha$ - the slope angle of the paddle;

$\varphi$ - the angle of the particle friction along the paddle surface;

\section{$S$ - projection of the paddle width.}

The axial velocity of the translocation of the mixture share is defined using the equation:

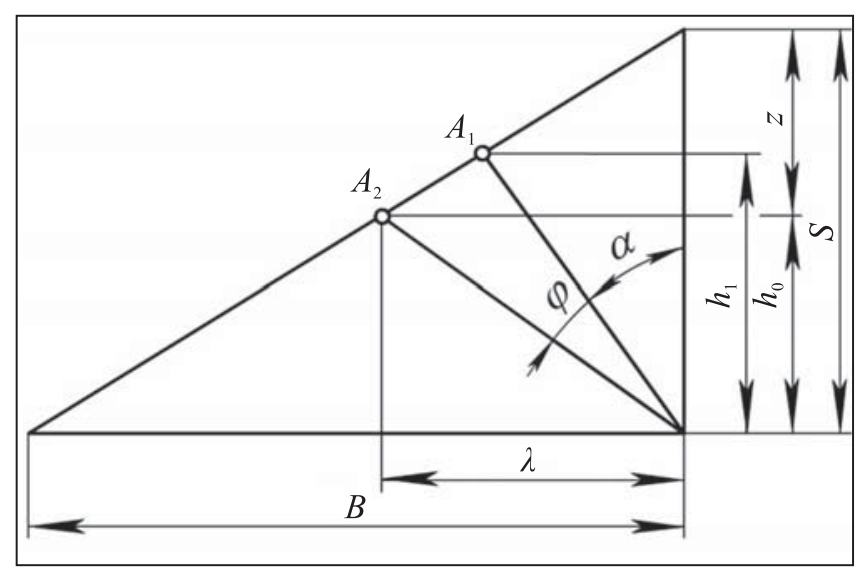

Fig. 4. The translocation of the material share in the axial direction while it passes the paddle

$$
\vartheta_{0}=S \cdot(1-\mu)=S \cdot\left[1-\frac{\sin \alpha \cdot(\sin \alpha+\varphi)}{\cos \varphi}\right],
$$

where $\mu$ - coefficient of the axial lagging behind of the shares depending on the angles $\alpha$ and $\varphi$.

The analysis of equations (1), (2) and (4) demonstrates that the translocation of mixture shares in the axial direction and the axial velocity of their translocation depend on the slope angle of the paddles towards the shaft axis of the mixer $\alpha$, the friction angle for the mixture along the paddle surface and the coefficient of axial lagging behind of the material shares of the mixture $\mu$ (Fig. 5, 6). With the increase in the angle $\alpha$ on condition of constant coefficient of friction $f$ the axial lagging behind of the translocation of mixture shares decreases, and with the constant slope angle of the paddle $\alpha$ on condition of increasing the coefficient of friction $f$, there is also an increase in 


\section{CHERNOVOL et al.}

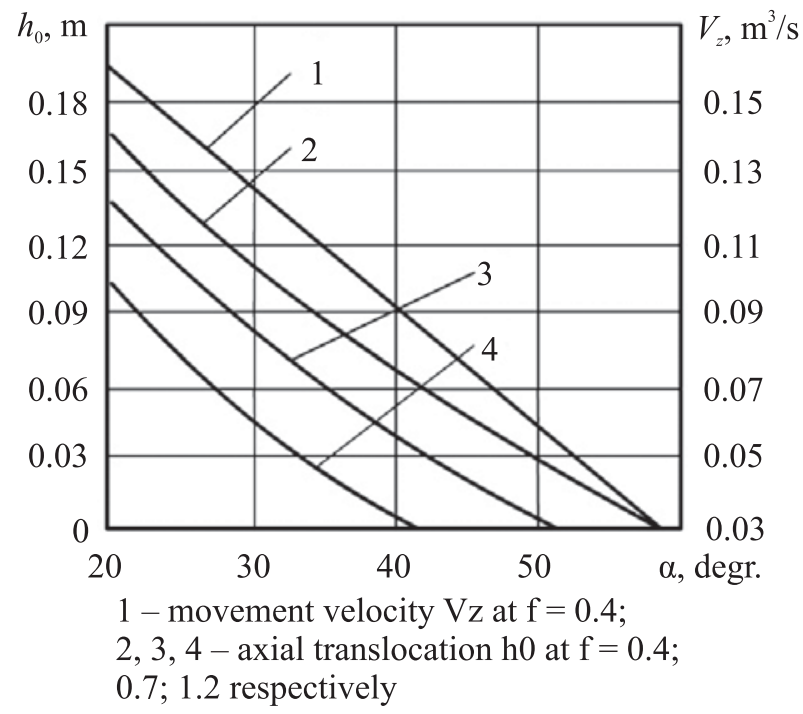

Fig. 5. The dependence of the value of the axial translocation $h_{0}$ and the axial velocity of translocation $V_{z}$ of the mixture shares on the slope angle of the paddles $\alpha$

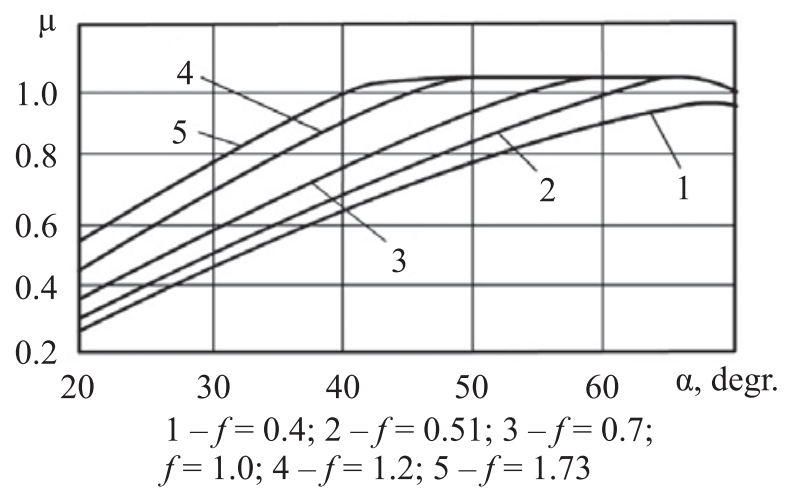

Fig. 6. The dependence of the coefficient of the axial lagging behind of the mixture shares on the angle $\alpha$ and the friction coefficient $f$

axial lagging behind and a decrease in the axial velocity of their movement.

For flat paddles with the slope angle $\alpha=40 \ldots 50^{\circ}$ there occur dead spots at the coefficient of friction $f \geq 0.6 \ldots 0.7$, which does not correspond to the technological requirements to mixing the feeds, and discrete particles have only rotational movements.

In the process of the movement of the mixer, when the mixture is separated by paddles, the shares receive the impulse from radial and normal effort $P_{p}^{\prime}=P_{H} \cdot \cos \alpha$ and $P_{p}^{\prime}=P_{H} \cdot \sin \alpha(\alpha-$ the slope angle for the paddle towards the rotation axis of the shaft).

In addition, the normal component of the force $R$ in the plane of the movement of shares along the paddle leads to the friction force $F=f \cdot P_{H}$, which is directed against the relative movement of shares along the paddle. The friction force $F$ is divided into the circular and axial components:

$$
\begin{aligned}
& F^{\prime}{ }_{p}=F \cdot \sin \alpha=f \cdot P_{H} \cdot \sin \alpha, \\
& F^{\prime}{ }_{o}=F \cdot \cos \alpha=f \cdot P_{H} \cdot \cos \alpha .
\end{aligned}
$$

Taking the received vectors into consideration by the movement directions, we receive the circular and axial efforts:

$$
\begin{aligned}
& P_{p}=P_{p}{ }^{\prime}+F_{p}{ }_{p}=P_{H} \cdot(\cos \alpha+f \cdot \sin \alpha), \\
& P_{o}=P_{o}^{\prime}{ }_{o}+F_{o}{ }_{o}=P_{H} \cdot(\sin \alpha-f \cdot \cos \alpha) .
\end{aligned}
$$

In case of incomplete filling of the mixer tank the normal component $P_{H}$ is defined using the formula:

$$
P_{H}=9.81 \gamma \cdot h_{\text {aver. }} \cdot F_{l} \cdot \operatorname{tg}^{2}\left(45+\frac{\varphi}{2}\right),
$$

where $h_{\text {aver. }}$ - average depth of the largest depression on the paddle, $\mathrm{m}$;

$F_{l}$ - projection of the paddle area on the direction of the rotation of the mixer, $\mathrm{m}^{2}$;

$\varphi$ - internal friction angle, degrees;

$\gamma$ - bulk weight of the mixture, $\mathrm{kg} / \mathrm{cc}$.

The required power of the drive of the mixer paddles is defined using the equation, kilowatt:

$$
N p=\frac{1}{1000}\left(P_{p} v_{p}+P_{o} v_{o}\right) \cdot Z_{p},
$$

where $Z_{p}$ - the number of paddles, which are simultaneously submerged into the feeding mixture.

Therefore, the total power of the mixer drive is defined as follows:

$$
\begin{aligned}
N_{m}=N_{h p}+N_{f p}+ & N_{h f r}+N_{f s t}+N_{f}+N_{h o r p}+ \\
& +N_{f}+N_{\eta_{m}},
\end{aligned}
$$

where $N_{h p}, N_{f p}, N_{h s t}, N_{f s t}, N_{f}, N_{\text {hor: } p}, N_{f}, N_{\eta_{m}}$ - power losses on the drive regarding the helical and flat paddles, frames of helical and flat paddles, radial fingers, horizontal pipes, friction of the mixer from the body and bearings of the shaft, kilowatt.

$$
N h p=\frac{P_{p} \vartheta_{p}+P_{o} \vartheta_{o}}{10^{3}} \cdot Z_{p}
$$

The power on the drive of helical and flat paddles: where $P_{p}, P_{o}-$ circular and axial effort, $\mathrm{H} ; \vartheta_{p}, \vartheta_{o}-$ circular and axial velocity of the mixture movement, $\mathrm{m} / \mathrm{s}$; $Z_{p}$ - number of simultaneously submerged paddles.

The power on the drive of frames of helical and flat paddles

$$
N_{f r}=\frac{M_{f r} \cdot Z_{f r} \cdot \omega}{10^{3}}
$$




\section{STUDY OF THE PROCESS OF PREPARING FEEDING MIXTURES USING THE COMPOSITE MIXER}

where $M_{f r}$ - rotational moment from the force of resistance of the frame, $H \cdot m$.

$$
M_{f r}=g \cdot l \cdot \frac{R}{2} \cdot h_{\text {aver }} \cdot \alpha \cdot \gamma \cdot \operatorname{tg} \varphi, H \cdot m,
$$

where $l$ - frame length, $\mathrm{m} ; \frac{R}{2}$ - ratio of the frame length to the resistance force, $\mathrm{m}$;

$h_{\text {aver }}-$ average depth of submerging the frame into the feed mass, m;

$\alpha$ - frame width, $\mathrm{m}$;

$\varphi$ - angle of feed slope, degrees.

The power on the drive of radial fingers, kilowatt:

$$
N_{n}=\frac{M_{n} \cdot Z_{n} \cdot \omega}{10^{3}},
$$

where $M_{n}$ - rotational moment from the force of resistance of the finger, $H \cdot m$.

$$
M_{f}=P_{f} \cdot l_{f} \cdot d_{f} \cdot R_{f},
$$

where $P_{f}$ - the relative resistance of the mixture, $H / \mathrm{m}^{2}$; $l_{f}$ - finger length, $\mathrm{m}$;

$d_{f}$ - finger diameter, $\mathrm{m}$;

$R_{f}$ - average radius of rotation for the fingers, $\mathrm{m}$.

The power on the drive of horizontal pipes, kilowatt:

$$
N_{\text {horp. }}=\frac{M_{p} \cdot Z_{p} \cdot \omega}{10^{3}},
$$

where $M_{p}$ - rotational moment from the resistance force of the horizontal pipe, $\mathrm{H} / \mathrm{m}$.

$$
\begin{array}{r}
M_{p}=P_{f} \cdot L \cdot d_{p} \cdot R_{p} \\
\text { CONCLUSIONS }
\end{array}
$$

The usage of the composite belt-paddle mixer can enchance the efficiency of the technology of preparing completely balanced feeding mixtures for cattle. The suggested construction of the mixer ensures the homogeneity of the mixture $V_{0}=95 \ldots 98 \%$ and required technological efficiency and reliability of performing the process with minimal energy losses which corresponds to the active zootechnic requirements $\left(V_{0}=\right.$ $90 \ldots 92 \%$ ) to the homogeneity of preparing complete mixtures for cattle.

Дослідження процесу приготування кормових сумішей комбінованим змішувачем

М. І. Черновол, М. О. Свірень, Р. В. Кісільов

Центральноукраїнський національний технічний університет

Пр. Університетський, 8, Кропивницький,
Україна, 25030, e-mail: rektor@kntu.kr.ua, kaf_sgm_kntu@ukr.net, ruslan_vik@ukr.net

Мета. Підвищення якості та удосконалення технологічного процесу змішування кормів за рахунок застосування нової конструкції змішувача та обгрунтування його раціональних параметрів. Методи. теорії математичного моделювання, основ машиновикористання в тваринництві. Результати. Розроблено розрахункову модель функціонування конструктивно-технологічної схеми комбінованого змішувача і математичну модель динамічної взаємодії лопатей мішалки 3 кормовим монолітом. Встановлено, що технологічна ефективність приготування однорідної суміші залежить від фізико-механічних властивостей iï компонентів, впливу і взаємодії форми і геометричних параметрів атакуючої поверхні лопатей, кута нахилу, кроку установки та режимів роботи змішувача. Висновки. Результати проведених досліджень підтверджують можливість підвищення ефективності технології приготування повноцінних збалансованих кормосумішей для ВРХ шляхом інтенсифікації процесу змішування 3 застосуванням конструкції комбінованого стрічковолопатевого змішувача, розробкою теоретичних основ взаємодії компонентів корму з його робочими органами та обгрунтуванням їх основних конструктивних та технологічних параметрів.

Ключові слова: змішувач кормів, корми, тваринництво, лопатева мішалка, кормосуміш, зоотехнічні вимоги

\section{Исследование поцесса приготовления кормовых смесей комбинированным смесителем}

\author{
М. И. Черновол, Н. А. Свирень, Р. В. Кисилев \\ Центральноукраинский национальный \\ технический университет \\ Пр. Университетский, 8, Кропивницкий, \\ Украина, 25030, \\ e-mail: rektor@kntu.kr.ua, \\ kaf_sgm_kntu@ukr.net,ruslan_vik@ukr.net
}

Цель. Повышение качества и совершенствования технологического процесса смешивания кормов за счет применения новой конструкции смесителя и обоснование его рациональных параметров. Методы. теории математического моделирования, основ машиноиспользования в животноводстве. Результаты. Разработана расчетная модель функционирования конструктивно-технологической схемы комбинированного смесителя и математическая модель динамического взаимодействия лопаток мешалки с кормовым монолитом. Установлено, что технологическая эффективность приготовления однородной смеси зависит от физико-механических свойств ее компонентов, влияния и взаимодействия формы и геометрических параметров атакующей поверхности лопаток, угла наклона, шага 


\section{CHERNOVOL et al.}

установки и режимов работы смесителя. Выводы. Результаты проведенных исследований подтверждают возможность повышения эффективности технологии приготовления полноценных сбалансированных кормосмесей для КРС путем интенсификации процесса смешивания с применением конструкции комбинированного ленточно-лопастного смесителя, разработкой теоретических основ взаимодействия компонентов корма с его рабочими органами и обоснованием их основных конструктивных и технологических параметров.

Ключевые слова: смеситель кормов, корма, животноводство, лопастная мешалка, кормосмеси, зоотехнические требования.

\section{REFERENCES}

1. Kravchuk VI, Lutsenko MM, Mechta MP. Progressive technologies of gathering, preparing and distributing feeds. Scientific-practical textbook. 2008:104 p.

2. Lazarevych AP. Single-type feed mixtures for dairy cattle. Tvarynnytstvo Ukrayiny. 2007;(4):33-5

3. Adgidzi D, Mu'azu A, Olorunsogo ST, Shiawoya EL. Design considerations of mixer-pelleting machine for processing animal feeds. $7^{\text {th }}$ annual engineering conference, School of Engineering and Engineering Technology, FUT Minna. 28-30 June 2006.

4. Khmeliovsky VS. Estimation of the balance in mixing feeds. Collection of theses of reports at the XII International scientific-practical conference "Obukhiv Readings" NUBIP Ukrayiny. K., 2017:77-8.

5. Revenko I., Revenko Yu. Quality of preparation and efficiency of using concentrated and combined fodder. MOTROL Commission of Motorization and Energetics in Agriculture. 2013;15(3):356-61. http://agro.icm.edu. $\mathrm{pl} /$ agro/element/bwmeta1.element.agro-5bafa802-c1cc4705-acd3-e3af4d984d88/c/356-361.pdf

6. Shevchenko I, Pavlichenko V, Lykhodid V, Zabudchenko $V$. Analysis of the constructions of the technical means to produce wet highly digestible food. Construction, production, and exploitation of agricultural machinery: state interdepartmental scientific-practical art. KNTU, 2013; Iss. 43, p. 1:179-85. http://dspace.kntu.kr.ua/jspui/ handle/123456789/2701

7. Revenko II, Brahinets MV, Rebenko VI. Machinery and equipment for animal breeding. K.: Kondor, 2009:730 p. Access mode: http://www.twirpx.com/file/2085032/

8. Shaysky V, Milko D, Kolomiez S, Boltyanskyi B, Semenzov $V$. Quality of ratio components mixing is basis of increase in the animal productivity. Scientific bulletin of TDATU. 2013;3(1):43-50. http://nauka.tsatu.edu.ua/e-journalstdatu/pdf1t3/11SVVIAP.pdf

9. Zavrazhnov AI, Nikolaev DI. Mechanization of preparing and storing feeds. M.: Agropromizdat, 1990:336 p.

10. Shatsky $V V$. Mathematical modelling of the dynamics in density and quality of feeding mixtures for animals. Scientific bulletin of TDATU. 2012;2(2):3-19. Access mode: http:/www.irbis-nbuv.gov.ua/cgi-bin/irbis_nbuv/ cgiirbis_64.exe?C21COM=2\&I21DBN=UJRN\&P21D $\mathrm{BN}=\mathrm{UJR}$ N \&IMAGE_FILE_DOWNLOAD $=1 \&$ Image file_name=PDF/Vkhdtusg_2014_144_32.pdf

11. Shabelnyk BP, Troyanov MM. Theory and calculations of machinery for animal breeding. Kharkiv: KhDTUSG, 2002:216 p.

12. Marchenko AYu., Serga GV, Frolov VYu, Sysoev DP. Mechanic-technological substantiation of the process of mixing concentrated feeds using cylindrical propeller driven drums. Monograph. KubGAU, Krasnodar. 2013:112 p. 